\title{
Xylanase and Phytase Supplementation in the De-oiled Rice Bran (DORB) based Diet Improves the Growth Performance of Labeo rohita
}

\author{
Amit Ranjan, Narottam Prasad Sahu* , Ashutosh Dharmendra Deo, \\ H. Sanath Kumar, Sarvendra Kumar and Kamal Kant Jain \\ Central Institute of Fisheries Education, Mumbai, India \\ *Corresponding author
}

\section{A B S T R A C T}

A 60-day experiment was conducted to study the effect of xylanase and phytase supplementation in the DORB based diet on growth performance of Labeo rohita.

Keywords

De-oiled Rice bran (DORB), Labeo rohita, Xylanase, Phytase, Growth, Body composition.

Article Info

Accepted:

21 May 2017

Available Online:

10 June 2017
Two iso-nitrogenous (crude protein-14\%) test diets (T1-DORB based diet, T2phytase and xylanase supplemented diet) were formulated. Sixty (60) juveniles of $L$. rohita, with an average weight $5.01 \pm 0.02 \mathrm{~g}$ were stocked in six uniform size plastic rectangular tank in triplicates with 10 fishes per tank following a completely randomized design (CRD). At the end of the experiment growth performance and nutrient utilization of $L$. rohita were assessed and found that exogenous enzyme supplementation @ $0.01 \%$ in the DORB based diet significantly $(\mathrm{p}<0.05)$ improved the growth performance and nutrient utilization (weight gain \% from $63.6 \%$ to $79.7 \%$, SGR from 0.82 to 0.98 , PER from 2.01 to 2.44 and FCR reduced from 3.57 to 2.92 ) of L. rohita. Carcass composition of fishes did not vary significantly. Hence, the experiment concludes that exogenous enzyme supplementation of xylanase and phytase in the DORB based diet improves the growth performance of L. rohita.

\section{Introduction}

De-oiled rice bran (DORB) is one of the major ingredient used in the fish feed. DORB is the by-product after extraction of oil from rice bran. At present about 7.0 MT of ingredients are being used for farm-made fish production (Ramakrishna et al., 2013). The current aquaculture production of the country (4.3 MMT) which is projected to reach 12.7 MMT by the year 2030 as reported by World Bank report (Msangi et al., 2013). Considering the total aquafeed production of India which is about $1 \mathrm{MMT}$ as reported by
Alltech (2014) is set to reach around 3 MMT by the year 2030 but the feed demand will be around 23 MMT hence the major part of feed will be the Mash feed that mainly contains DORB (about 80-85 \%) (Ramkrishna et al., 2013). The carps together contribute to more than $82 \%$ of total aquaculture production in India. About $97 \%$ of the carp feeds used by Indian farmers are farm-made (Ramkrishna $e t$ al., 2013). But looking into the DORB production of India which is presently about 6 MMT is not going to increase to support the 
demand that will be required for Indian Major Carp (IMC) and other cultured fish. Hence, the strategic utilization of DORB to reduce FCR is required which will pave the way to bring down the demand and supply gap of DORB.

Most of the ANFs present in rice bran is protein in nature and heat labile except phytate (Juliano, 1985). Rice bran also contains a relatively high percentage of nonstarch polysaccharide (NSP), with arabinose and xylose being predominant (Annison et al., 1985). This may have an adverse effect on the digestion of some dietary components. Phytic acid is an ANF found in many plant ingredients which chelate with various macroand micronutrients and negatively affects their digestibility (Sugiura et al., 2001; Usmani and Jafri, 2002; Baruah et al., 2005, 2007; Debnath et al., 2005). Dietary microbial phytase supplementation has been shown to be very promising in several fish species which nullify the negative effect of phytate and improves the nutrients digestibility and growth performance of fish (Yan and Reigh, 2002; Vielma et al., 2004; Debnath et al., 2005; Baruah et al., 2007).

Non-starch polysaccharide (NSP) are considered as an unavailable energy source for fish, as they lack NSP digestive enzymes (Castillo and Gatlin, 2015; Sinha et al., 2011). NSP dilutes the energy concentration of the feeds and reduces the digestibility/bioavailability of nutrients by interfering with the digestion and absorption (NRC, 2011; Castillo and Gatlin, 2015). NSP also interfere with the access of digestive enzymes to their substrates (Xu et al., 2009; Jiang et al., 2014; Magalhães et al., 2015).

Dietary NSPase supplementation to plant based feedstuffs diets improves nutrients utilization and reduces environmental faecal wastes. NSPase were shown to increase the growth performance, feed conversion, and protein utilization efficiency in juvenile Japanese seabass (Lateolabrax japonicas; Ai et al., 2007), hybrid tilapia (Oreochromis niloticus $\times$ Oreochromis aureus; Lin et al., 2007); Caspian salmon (Salmo trutta caspius; Zamini et al., 2014) and African catfish (Clarias gariepinus; Yildirim and Turan, 2010). The beneficial effects of exogenous non-starch polysaccharidases (NSPase) may be directly related to NSP hydroxylation, which improves carbohydrate digestibility, or to the improvement of other nutrients digestibility (Adeola and Bedford, 2004; Ai et al., 2007; Adeola and Cowieson, 2011; Yiğit et al., 2014). Xylanase hydrolyses cell wall components in plant and efficiently reduces NSP content in plant ingredient which in turn improves protein utilization and growth performance in several fish experiment.

As it is clear from above discussion that DORB contains various ANFs, NSP that impede the nutrient utilization of rice bran. Hence, to increase the nutrient availability and improve the growth performance and nutrient utilization of Labeo rohita, the present study has conducted to evaluate the effect of xylanase and phytase supplementation on maximizing utilization of de-oiled rice bran in the diet of Labeo rohita.

\section{Materials and Methods}

\section{De-oiled Rice bran}

De-oiled rice bran was supplied by Vaighai Agro Products Ltd., Tamil Nadu, India. Before using de-oiled rice bran in feed, it was finely ground and sieved to get uniform particle size.

\section{Exogenous enzymes}

Microbial phytase from E. coli (Quantum blue, $500 \mathrm{U} / \mathrm{kg}$ ) and xylanase (Econase $\AA \mathrm{XT}$, 
$16000 \mathrm{U} / \mathrm{kg}$ ) was supplied by AB Vista, Wiltshire, UK.

\section{Diet preparation}

The experimental diets were prepared using DORB. Two experimental diets (T1 and T2) were prepared using ingredients given in table 1. Diets were prepared by blending the ingredients except the vitamin mineral mix to make a dough with the water. Then it was steamed for $30 \mathrm{~min}$. in a pressure cooker. After cooling the dough, vitamin-mineral mix, oil and enzymes were added to the different diets as specified in the formulation. The dough was then mixed properly and pressed through a semi-automatic pelletizer (Uniextrude-Single screw extruder S.B. Panchal and Company, Mumbai, India) to get uniform sized pellets $(0.7-0.8 \mathrm{~mm})$, which were spread on a sheet of paper and dried at room temperature. After drying, the pellets were packed in polythene bags, sealed and kept at $-20^{\circ} \mathrm{C}$ for storage until use.

\section{Fish and facilities}

The experiment was conducted at wet laboratory of the CIFE, Mumbai over a period of 60 days from February to April, 2016. Subsequently, the laboratory work was carried out in Fish Nutrition, Biochemistry and Physiology laboratory of Central Institute of Fisheries Education. Experimental fishes were procured from a commercial farm from Shramjivi Janta Sahayak Mandal (NGO) Taluka-Mahad, District-Raigarh, Mumbai. The fishes were transported to the wet laboratory in oxygen packed polyethylene bags. In order to ameliorate the handling stress the fishes were given a mild salt (4 ppm) treatment and vitamin C (4 tablets per 500 lit of water) treatment the next day. The stock was acclimatized for a period of 30 days before start of the experiment. Animals used for the experiment were juveniles of Labeo rohita, with an average weight $5.01 \pm 0.02 \mathrm{~g}$ (4.9g-5.1g). The experimental setup consisted of 6 uniform size plastic rectangular tank (80 $\mathrm{cm} \times 57 \mathrm{~cm} \times 42 \mathrm{~cm}, 150$ L capacity) covered with perforated lids. Sixty (60) fishes were randomly distributed and stocked in two distinct experimental groups following a completely randomized design (CRD) in triplicates with 10 fishes per tank.The total volume of the water in each tub was maintained at $120 \mathrm{~L}$ throughout the experimental period. Round the clock aeration was provided. The aeration pipe in each tank was provided with an air stone and a plastic regulator to control the air pressure uniformly in all the tanks. Feed was fed ad libitum twice daily at 10:00 am in the morning and 04:00 $\mathrm{pm}$ in the afternoon. Water quality parameters like $\mathrm{DO}, \mathrm{pH}$, free $\mathrm{CO}_{2}$, hardness, ammonia, nitrite and nitrate were also estimated periodically as per APHA method (APHA, 1998) to keep the water quality optimal for sustained culture of fish.

\section{Fish sampling and proximate analysis}

At the end of feeding trial fishes were fasted for the $24 \mathrm{hrs}$. and then weighed for calculating the growth performance and nutrient utilization parameters like weight gain (\%), specific growth rate (SGR), feed conversion ratio (FCR), protein efficiency ratio (PER). Body indices parameters like hepato-somatic index and intestine-somatic index was also calculated by taking liver and intestine weight to whole body weight of six fishes per replicate. Survival (\%)was calculated at the end of experiment by dividing total no. of fish harvested at the end of experiment to the total number of fish stocked at the beginning of the experiment multiplied by 100.Six fish per replicate were sampled and anesthetized with clove oil (50 $\mu 1 . L^{-1}$ ) before killing the fish. For proximate analysis all the dissected fishes from every replicate were collected, weighed and kept in pre-weighed petri plates. Prior to proximate analysis the test diets and sampled fish in 
triplicates were dried in hot air oven at $100^{\circ} \mathrm{C}$ \pm 2 . After complete drying the different test diets and fishes were ground into the fine powder with a pestle and mortar. Proximate composition of the test diets and fish were analyzed following AOAC method (AOAC, 1995).

\section{Calculations}

Weight gain (\%), specific growth rate (SGR), feed conversion ratio (FCR), protein efficiency ratio (PER), hepato-somatic index (HSI), intestinal-somatic index (ISI) and survival (\%) were calculated as given below

Weight gain $(\%)=\frac{\text { Final weight }- \text { Initial Weight }}{\text { Initial weight }} \times 100$

$\mathrm{SGR}=\frac{\log _{\mathrm{e}} \text { Final weight }-\log _{\mathrm{e}} \text { Initial weight }}{\text { Number of days }} \times 100$

FCR $=\frac{\text { Feed given (Dry Weight) }}{\text { Body Weight Gain (Wet Weight) }}$

PER $=\frac{\text { Net weight Gain (wet weight) }}{\text { protein fed }}$

HSI $=\frac{\text { liver weight }(\mathrm{g})}{\text { weight of fish }(\mathrm{g})} \times 100$

VSI $=\frac{\text { viscera weight }(\mathrm{g})}{\text { weight of fish }(\mathrm{g})} \times 100$

Survival $(\%)=\frac{\text { total number of harvested fish }}{\text { total number of stocked fish }} \times 100$

\section{Results and Discussion}

\section{Water quality Parameter}

Water quality parameters were estimated periodically as per APHA method (APHA, 1998) and the range of all parameter observed during experimental period were as follows: temperature $\left(27.2-28^{\circ} \mathrm{C}\right)$, DO $\left(6.5-7.2 \mathrm{mgL}^{-1}\right)$, $\mathrm{pH}$ (7.5-7.6), free $\mathrm{CO}_{2}$ (not detected), hardness (228-240 mg. $\left.\mathrm{L}^{-1}\right)$, ammonia (0.14$\left.0.19 \mathrm{mg} . \mathrm{L}^{-1}\right)$, nitrite $\left(0.001-0.002 \mathrm{mg} . \mathrm{L}^{-1}\right)$ and nitrate $\left(0.02-0.04 \mathrm{mg} . \mathrm{L}^{-1}\right)$.

\section{Proximate composition of Experimental} diets

Proximate composition of the experimental diets viz. dry matter(\%), ash (\%), crude protein $(\%)$,ether extract $(\%)$ and crude fibre (\%) were analysed which is presented in table 2. Dry matter (\%) vary from $92.30 \%$ to 92.39 $\%$, ash (\%) vary from $13.70 \%$ to $13.79 \%$,crude protein (\%) vary from $14.02 \%$ to $14.15 \%$, ether extract $(\%)$ vary from 7.44 $\%$ to $7.50 \%$ and crude fibre $(\%)$ vary from $16.12 \%$ to $16.41 \%$ which were found statistically insignificant $(\mathrm{p}>0.05)$ among treatments.

Growth performance, nutrient utilization, body indices and survival (\%) of different treatments

Highest WG \%, SGR and PER and lowest FCR were recorded for the fishes fed with DORB supplemented with exogenous enzymes (phytase and xylanase), as compared to the fish fed with the only DORB without enzyme supplementation. Exogenous enzyme supplementation to DORB resulted improvement in weight gain \% from $63.6 \%$ to $79.7 \%$, SGR from 0.82 to 0.98 , PER from 2.01 to 2.44 and FCR reduced from 3.57 to 2.92 of $L$. rohita. Body indices parameter like HSI varied from 0.61 to 0.74 and ISI varied from 3.87 to 4.04 which were not statistically different treatments. Survival $(\%)$ of the two treatments were $100 \%$ (T1) and 93\% (T2) which were not significantly different (p>0.05) (Table 3).

\section{Body composition of fishes among different treatments}

Proximate composition of the whole body of fish is presented in table 4. Body composition 
of fishes were analysed following AOAC method (AOAC, 1995) in which moisture (\%) of fishes varies from 76.05 to $76.42 \%$,crude protein from $13.17 \%$ to 13.99 , ssh (\%) from $3.56 \%$ to $3.58 \%$, and ether extract from $3.01 \%$ to $3.23 \%$ which were also not different among treatments $(\mathrm{p}>0.05)$.

Higher crude fibre content and non-starch polysaccharide along with phytate are the major limitation for utilization of DORB in the mono-gastric animal including fish. The non-starch polysaccharide altogether constitutes $59.97 \%$ of the DORB (Malathi and Devegowda, 2001), which is not digested by fish (Francis et al., 2001; Glencross et al., 2007). The presence of NSP in the diets leads to increase gut viscosity, prevent access to the endogenous enzyme to nutrients and form a physical barrier and hence elicit an antinutritive effect (Storebakken et al., 1998; Refstie et al., 1999).

Table.1 Composition of experimental diets

\begin{tabular}{lll}
\hline Ingredients $(\%)$ & $\mathrm{T} 1$ & $\mathrm{~T} 2$ \\
\hline DORB & 90 & 90 \\
CMC & 2 & 2 \\
Cod liver oil & 3.5 & 3.5 \\
Soybean oil & 3.5 & 3.5 \\
Vitamin- mineral mix & 1 & 1 \\
Phytase & 0 & 0.01 \\
Xylanase & 0 & 0.01 \\
\hline
\end{tabular}

T1- DORB without enzyme, T2- DORB with enzyme

DORB $=$ De-0ioled Rice Bran, $\mathrm{CMC}=$ Carboxy Methyl Cellulose

Composition of Vitamin- mineral mix (PREMIX PLUS) (quantity. $\mathrm{kg}^{-1}$ )

Vitamin A (55,00,000 IU); Vitamin D3 (11,00,000 IU); Vitamin B2 (2,000 mg); Vitamin E (750 mg); Vitamin K (1,000 mg); Vitamin B1 (100 mg), Vitamin B2 (200 mg), Vitamin B6 (1,000 mg); Vitamin B12 (6 mcg); Calcium Pantothenate (2,500 mg); Nicotinamide (10 g); Choline Chloride (150 g); Mn (27,000 mg); I (1,000 mg); Fe (7,500 $\mathrm{mg}) ; \mathrm{Zn}(5,000 \mathrm{mg}) ; \mathrm{Cu}(2,000 \mathrm{mg}) ; \mathrm{Co}(450)$ (10g);Selenium(125mg).

Table.2 Proximate composition of Test Diets (\% Dry matter basis)

\begin{tabular}{lll}
\hline Proximate composition & T1 & T2 \\
\hline Dry matter & $92.30 \pm 0.22$ & $92.39 \pm 0.26$ \\
Ash & $13.79 \pm 0.03$ & $13.70 \pm 0.08$ \\
CP & $14.02 \pm 0.03$ & $14.15 \pm 0.10$ \\
EE & $7.50 \pm 0.02$ & $7.44 \pm 0.17$ \\
CF & $16.12 \pm 0.20$ & $16.41 \pm 0.02$ \\
\hline
\end{tabular}

T1- DORB without enzyme, T2- DORB with enzyme

All values are Mean $\pm \mathrm{SE}$, obtained from three replicates.

$\mathrm{CP}(\%)=$ Crude Protein; EE $(\%)=$ Ether Extract; $\mathrm{CF}(\%)=$ Crude Fibre; SE=Standard Error. 
Table.3 Growth performance, Body indices and Survival (\%) of Labeo rohita fed with or without enzyme supplemented DORB

\begin{tabular}{llll}
\hline Treatments & T1 & T2 & p-value \\
\hline WG\% & $63.61^{\mathrm{a}} \pm 2.66$ & $79.71^{\mathrm{b}} \pm 1.20$ & 0.005 \\
SGR & $0.82^{\mathrm{a}} \pm 0.03$ & $0.98^{\mathrm{b}} \pm 0.01$ & 0.006 \\
FCR & $3.57^{\mathrm{b}} \pm 0.13$ & $2.92^{\mathrm{a}} \pm 0.04$ & 0.008 \\
PER & $2.01^{\mathrm{a}} \pm 0.07$ & $2.44^{\mathrm{b}} \pm 0.03$ & 0.005 \\
HSI & $0.61 \pm 0.05$ & $0.74 \pm 0.03$ & 0.095 \\
ISI & $3.87 \pm 0.15$ & $4.04 \pm 0.32$ & 0.661 \\
Survival \% & 100 & 93 & 0.374 \\
\hline
\end{tabular}

T1- DORB without enzyme, T2- DORB with enzyme

All values are Mean \pm SE, obtained from three replicates. Values in the same row with different superscript letters are significantly different $(\mathrm{p}<0.05)$.

WG \%= Weight Gain \%, SGR= Specific Growth Rate, FCR=Feed Conversion Ratio, PER= Protein Efficiency

Ratio, HSI = hepato-somatic index, ISI= intestinal-somatic index, SE=Standard Error.

Table.4 Whole body composition of Labeo rohita fed with or without Enzyme supplemented DORB

\begin{tabular}{lllll}
\hline Treatments & Moisture (\%) & CP (\%) & ASH (\%) & EE (\%) \\
\cline { 2 - 3 } T1 & $76.05 \pm 0.51$ & $13.17 \pm 0.32$ & $3.56 \pm 0.19$ & $3.23 \pm 0.17$ \\
T2 & $76.42 \pm 0.14$ & $13.99 \pm 0.23$ & $3.58 \pm 0.16$ & $3.01 \pm 0.24$ \\
p-value & 0.521 & 0.105 & 0.955 & 0.092 \\
\hline
\end{tabular}

T1- DORB without enzyme, T2- DORB with enzyme

$\mathrm{CP}(\%)=$ Crude Protein; EE $(\%)=$ Ether Extract; SE=Standard Error.

In fish, their negative influences may be either because of binding to bile acids or obstructing action against digestive enzyme activity and movement of substrates in their intestine (Storebakken et al., 1998). Digestive enzymes in fish that specifically hydrolyze the $\beta$-glycosidic bonds of non-starch polysaccharides are very low or even nonexistent (Krogdahl et al., 2005; NRC, 2011). Supplementation of exogenous NSP enzymes leads to the decrease in digesta viscosity, and improve digestibility of amino acids, protein, lipid and starch which contributes to improved feed utilization and growth performance of animals (Classen, 1996; Cowieson et al., 2006). Phytate is another important anti-nutritional factor which is associated with DORB. Phytate chelates with divalent element such as $\mathrm{Ca}^{2+}, \mathrm{Zn}^{2+}, \mathrm{Fe}^{2+}$, $\mathrm{Mn}^{2+}$ and forms insoluble chelate complex (Papatryphon et al., 1999).

They also combine with protein insoluble complex and reduce their utilization efficiency, activity and digestibility (Liu et al., 1998; Sugiura et al., 2001). Fishes are unable to digest Phytate phosphorus as they are devoid of intestinal phytase (Pointillart $e t$ al., 1987; Debnath et al., 2005). The exogenous phytase supplementation leads to increase in the utilization of phytate phosphorus, other trace elements and protein, 
and the decrease in phosphorus discharged into water (Papatryphon et al., 1999; Vielma et al., 2002). Results from the present study demonstrated that strategy like exogenous enzyme supplementation to DORB based diet improves the growth performance and nutrient utilization of L. rohita significantly.

The exogenous enzyme supplementation to the DORB based diet led to higher weight gain, SGR, PER and lower FCR as compared to the DORB based diet in which exogenous enzyme was not supplemented. Similar, findings were also observed in Japanese sea bass, Lateolabrax japonicus (Ai et al., 2007; Zhang et al., 2009) large yellow croaker, Pseudosciaenacrocea (Zhang et al., 2006) and tilapia, Oreochromis niloticus $\times$ Oreochromis aureus (Lin et al., 2007), when their diet supplemented with exogenous nonstarch polysaccharide (NSP) enzymes and phytase, resulted in higher growth, feed utilization and digestive enzyme activities. Zamini et al., (2014) also found that Salmo trutta caspius fed the control diet without any exogenous enzyme exhibited lower growth and higher FCR than diets with supplemented enzymes, indicating that exogenous enzyme is beneficial for the growth of the fish. Most studies on other species also indicated that exogenous carbohydrases enzymes improved the weight gain and feed conversion ratio (Carter et al., 1994; Van et al., 1999; Bedford, 1995, 2000; Hlophe-Ginindza et al., 2015). In contrary to that there are several conflicting reports in which it was found that even no or adverse effect when carbohydrases enzymes were added to the animal feeds (Stone et al., 2003; Kazerani and Shahsavani, 2011; Yigit and Olmez, 2011). Similarly, Ogunkoya et al., (2006) and Farhangi and Carter (2007) did not find any effect on growth and feed efficiency of rainbow trout fed the diet supplemented with enzyme cocktail mix. HSI explains the relationship between liver weight and body weight. In present study, HSI did not vary significantly among the treatments, which is in accordance with the finding of Magalhães et al., (2016), who also observed no significant difference in the HSI of white seabream (Diplodussargus) juveniles fed high soybean meal diets supplemented with exogenous carbohydrases enzyme. Similarly, ISI explains the relationship between the weight of intestine and somatic weight of the fish. In present study, ISI were found similar (p>0.05). Fawole et al., (2016) also did not find any significant difference in the ISI of Labeorohita fed with rubber protein isolate. The whole body moisture $\%$, ash $\%$, crude protein $\%$ and ether extract $\%$ was similar among treatments $(\mathrm{p}>0.05)$. Our findings are consistent with the results of Adeoye et al., (2016), however, he finds a significant difference in moisture $\%$ when he fed formulated diet to tilapia with selected exogenous enzymes (Protease, lipase and Carbohydrases). Similarly, Yldirin and Turan (2010) also observed no significant difference in the whole body composition except crude protein (\%) of Clarius gariepinus fed with exogenous enzyme supplemented diet.

The addition of xylanase and phytase @ 0.01 $\%$ to the DORB based diets significantly improved the growth performance and nutrient utilization of Labeorohita. The present study demonstrated that DORB based diet along with supplementation of exogenous enzymes (xylanase and phytase) can be an effective strategy to bring down the FCR, which will not only bring down the future higher demand of DORB but will also give an effective tool to utilize DORB as sole source of ingredient in the feed of Labeorohita. This appears to be an effective strategy for utilization of farm feed which is mostly prepared from DORB.

\section{Acknowledgements}

The authors are very thankful to the Director, Central Institute of Fisheries Education, Versova, Mumbai, for providing all the 
facilities during the research work. The financial support given by the Indian Council of Agricultural Research, New Delhi, is also gratefully acknowledged. The authors are also sincerely acknowledging the support of Vaighai Agro Products Limited, Tamil Nadu and $A B$ Vista, India for supplying DORB and Enzymes free of cost for successful completion of this research work. First Authors is sincerely acknowledging the Dr. C.V. Kulkarni International Travel Grant which makes it possible for the first author to present his research paper during International Fisheries Symposium, 2016 at Phu Quoc Island, Vietnam.

\section{References}

Adeola, O. and Bedford, M.R. 2004. Exogenous dietary xylanase ameliorates viscosity-induced anti-nutritional effects in wheat-based diets for White Pekin ducks (Anas platyrinchos domesticus). Br. J. Nutr., 92: 87-94.

Adeola, O. and Cowieson, A.J. 2011. Opportunities and challenges in using exogenous enzymes to improve nonruminant animal production. J. Anim. Sci., 89: 3189-3218.

Adeoye, A.A., Jaramillo-Torres, A., Fox, S.W., Merrifield, D.L. and Davies, S.J. 2016. Supplementation of formulated diets for tilapia (Oreochromis niloticus) with selected exogenous enzymes: Overall performance and effects on intestinal histology and microbiota. Anim. Feed. Sci. Tech., 215: 133-143.

Ai, Q., Mai, K., Zhang, W., Xu, W., Tan, B., Zhang, C. and Li, H. 2007. Effects of exogenous enzymes (phytase, nonstarch polysaccharide enzyme) in diets on growth, feed utilization, nitrogen and phosphorus excretion of Japanese seabass, Lateolabrax japonicus. Comp. Biochem. Physiol., 147: 502-508.
Akhtar, M.S., Pal, A.K., Sahu, N.P., Ciji, A., and Meena, D.K. 2012. Effects of dietary Pyridoxine on growth and physiological responses of Labeo rohita fingerlings reared in high water temperature. Israeli J. Aquacult., 64: 16.

Alltech. 2014. Alltech Global Feed Survey Summary, 8p. Alltech Nicholasville, Kentucky, USA.

Annison, G., Moughan, P.J. and Thomas, D. V. 1995. Nutritive activity of soluble rice bran arabinoxylans in broiler diets. Br. Poult. Sci., 36: 479-488.

AOAC (Association of Official Analytical Chemists). 1995. Official Methods of Analysis of the Association Official Analytical Chemists, 16th ed. AOAC, Inc., Arlington, Virginia, USA.

APHA. 1998. Standard Methods for the Examination of Water and Wastewater, Washigton, DC, 20th Edition, pp.1220.

Baruah, K., Pal, A.K., Sahu, N.P., Jain, K.K., Mukherjee, S.C., and Debnath, D. 2005. Dietary protein level, microbial phytase, citric acid and their interactions on bone mineralization of Labeo rohita (Hamilton) juveniles. Aquacult. Res., 36: 803-812.

Baruah, K., Sahu, N.P., Pal, A.K., Jain, K.K., Debnath, D. and Mukherjee, S.C. 2007. Dietary microbial phytase and citric acid synergistically enhances nutrient digestibility and growth performance of Labeo rohita (Hamilton) juveniles at sub- optimal protein level. Aquacult. Res., 38: 109-120.

Bedford, M.R. 2000. Exogenous enzymes in monogastric nutrition-their current value and future benefits. Anim. Feed. Sci. Tech., 86:1-13.

Bedford, M.R. 1995. Mechanism of action and potential environmental benefits from the use of feed enzymes. Anim. Feed. Sci. Tech., 53: 145-155. 
Carter, C.G., Houlihan, D.F., Buchanan, B. and Mitchell, A.I. 1994. Growth and feed utilization efficiencies of seawater Atlantic salmon, Salmo salar L., fed a diet containing supplementary enzymes. Aquacult. Res., 25: 37-46.

Classen, H.L. 1996. Cereal grain starch and exogenous enzymes in poultry diets. Anim. Feed. Sci. Technol., 62: 21-27

Cowieson, A.J., Singh, D.N. and Adeola, O. 2006. Prediction of ingredient quality and the effect of a combination of xylanase, amylase, protease and phytase in the diets of broiler chicks. 1. Growth performance and digestible nutrient intake. Br. Poult. Sci., 47: 477-489.

Debnath, D., Pal, A.K., Sahu, N.P., Jain, K.K., Yengkokpam, S. and Mukherjee, S.C. 2005. Effect of dietary microbial phytase supplementation on growth and nutrient digestibility of Pangasius pangasius (Hamilton) fingerlings. Aquacult. Res., 36: 180-187.

Fawole, F.J., Sahu, N.P., Jain, K.K., Gupta, S., Shamna, N., Phulia, V., and Prabu, D.L. 2016. Nutritional evaluation of protein isolate from rubber seed in the diet of Labeo rohita: Effects on growth performance, nutrient utilization, whole body composition and metabolic enzymes activity. Anim. Feed. Sci. Tech., 219: 189-199.

Francis, G., Makkar, H.P. and Becker, K. 2001. Anti-nutritional factors present in plant-derived alternate fish feed ingredients and their effects in fish. Aquaculture, 199: 197-227.

Glencross, B.D., Booth, M. and Allan, G.L. 2007. A feed is only as good as its ingredients-a review of ingredient evaluation strategies for aquaculture feeds. Aquac. Nutr., 13: 17-34.

Hlophe Ginindza, S.N., Moyo, N.A., Ngambi, J.W. and Ncube, I. 2015. The effect of exogenous enzyme supplementation on growth performance and digestive enzyme activities in Oreochromis mossambicus fed kikuyu- based diets. Aquac. Res., 1-11.

Jiang, T.T., Feng, L., Liu, Y., Jiang, W.D., Jiang, J., Li, S.H., Tang, L., Kuang, S.Y. and Zhou, X.Q. 2014. Effects of exogenous xylanase supplementation in plant protein-enriched diets on growth performance, intestinal enzyme activities and microflora of juvenile Jian carp (Cyprinus carpio var. Jian). Aquac. Nutr., 20: 632-645.

Kazerani, H.R. and Shahsavani, D. 2011. The effect of supplementation of feed with exogenous enzymes on the growth of common carp (Cyprinus carpio). Iran. $J$. Vet. Res., 12: 127-132.

Krogdahl, A., Hemre, G.I. and Mommsen, T.P. 2005. Carbohydrates in fish nutrition: digestion and absorption in post-larval stages. Aquac. Nutr., 11: 103-122.

Lin, S., Mai, K. and Tan, B. 2007. Effects of exogenous enzyme supplementation in diets on growth and feed utilization in tilapia, Oreochromis niloticus x $O$. aureus. Aquac. Res., 38: 1645-1653.

Liu, B.L., Rafiq, A., Tzeng, Y.M. and Rob, A. 1998. The induction and characterization of phytase and beyond. Enzyme Microb. Technol., 22: 415-424.

Magalhães, R., Coutinho, F., Pousão-Ferreira, P., Aires, T., Oliva-Teles, A. and Peres, H. 2015. Corn distillers dried grains with solubles: Apparent digestibility and digestive enzymes activities in European seabass (Dicentrarchus labrax) and meagre (Argyrosomus regius). Aquaculture, 443: 90-97.

Magalhães, R., Lopes, T., Martins, N., DíazRosales, P., Couto, A., Pousão-Ferreira, P., and Peres, H. 2016. Carbohydrases supplementation increased nutrient utilization in white seabream (Diplodus sargus) juveniles fed high soybean meal diets. Aquaculture, 463: 43-50. 
Malathi, V., and Devegowda, G. 2001. In vitro evaluation of nonstarch polysaccharide digestibility of feed ingredients by enzymes. Poult. Sci., 80: 302-305.

Msangi, S., Kobayashi, M., Batka, M., Vannuccini, S., Dey, M.M. and Anderson, J.L. 2013. Fish to 2030: prospects for fisheries and aquaculture. World Bank Report, (83177-GLB).

National Research Council. 2011. Nutrient requirements of fish and shrimp. National academies press.

Ogunkoya, A.E., Page, G.I., Adewolu, M.A. and Bureau, D.P. 2006. Dietary incorporation of soybean meal and exogenous enzyme cocktail can affect physical characteristics of faecal material egested by rainbow trout (Oncorhynchus mykiss). Aquaculture, 254: 466-475.

Papatryphon, E., Howell Jr., and R.A., J.H.S. 1999. Growth and mineral absorption by striped bass Moronesaxatilis fed a plant feedstuff based diet supplemented with phytase. J. World Aquacult. Soc., 30: 161-173.

Ramakrishna, R., Shipton, T.A. and Hasan, M.R. 2013. Feeding and feed management of Indian major carps in Andhra Pradesh, India. Food and Agriculture Organization of the United Nations.

Refstie, S., Svihus, B., Shearer, K.D. and Storebakken, T. 1999. Nutrient digestibility in Atlantic salmon and broiler chickens related to viscosity and non-starch polysaccharide content in different soyabean products. Anim. Feed Sci. Technol., 79: 331-345.

Stone, D.A.J., Allan, G.L. and Anderson, A.J. 2003. Carbohydrate utilization by juvenile silver perch, Bidyanus bidyanus (Mitchell). IV. Can dietary enzymes increase digestible energy from wheat starch, wheat and dehulled lupin? Aquac. Res., 34: 135-147.

Storebakken, T., Shearer, K.D. and Roem, A. J. 1998. Availability of protein, phosphorus and other elements in fish meal, soy-protein concentrate and phytase-treated soy-protein-concentratebased diets to Atlantic salmon, Salmo salar. Aquaculture, 161: 365-379.

Sugiura, S.H., Gabaudan, J., Dong, F.M. and Hardy, R.W. 2001. Dietary microbial phytase supplementation and the utilization of phosphorus, trace minerals and protein by rainbow trout Oncorhynchus mykiss (Walbaum) fed soybean meal based diets. Aqua. Res., 32: 583-592.

Usmani, N. and Jafri, A.K. 2002. Influence of dietary phytic acid on the growth, conversion efficiency, and carcass composition of mrigal Cirrhinus mrigala (Hamilton) fry. J. World Aqua. Soc., 33: 199-204.

Van, W.J.H., Khalaf, K.A., Aartsen, F.J. and Tijssen, P.A.T. 1999. Balance trials with African catfish Clarias gariepinus fed phytase treated soybean meal based diets. Aquac. Nutri., 5: 135-142.

Vielma, J., Ruohonen, K. and Peisker, M. 2002. Dephytinization of two soy proteins increases phosphorus and protein utilization by rainbow trout, Oncorhynchus mykiss. Aquaculture, 204: $145-156$.

Vielma, J., Mäkinen, T., Ekholm, P. and Koskela, J. 2000. Influence of dietary soy and phytase levels on performance and body composition of large rainbow trout (Oncorhynchus mykiss) and algal availability of phosphorus load. Aquaculture, 183: 349-362.

Xu, B., Wang, Y., Li, J. and Lin, Q. 2009. Effect of prebiotic xylooligosaccharides on growth performances and digestive enzyme activities of allogynogenetic crucian carp (Carassius auratus 
gibelio). Fish Physiol. Biochem., 35: 351-357.

Yan, W., Reigh, R.C. and Xu, Z. 2002. Effects of fungal phytase on utilization of dietary protein and minerals, and dephosphorylation of phytic acid in the alimentary tract of channel catfish Ictalurus punctatus Fed an All- Plant- Protein Diet. J. World Aquac. Soc., 33: 10-22.

Yiğit, N.O., Koca, S.B., Didinen, B.I. and Diler, I. 2014. Effect of $\beta$-Mannanase and $\alpha$-Galactosidase Supplementation to Soybean Meal Based Diets on Growth, Feed Efficiency and Nutrient Digestibility of Rainbow Trout, Oncorhynchus mykiss (Walbaum). Asian-Australas. J. Anim. Sci., 27: 700.

Yildirim, Y.B. and Turan, F. 2010. Effects of exogenous enzyme supplementation in diets on growth and feed utilization in African catfish, Clarias gariepinus. $J$. Anim. Vet. Adv., 9: 327-331.
Zamini, A., Kanani, H.G., azamEsmaeili, A., Ramezani, S. and Zoriezahra, S.J. 2014. Effects of two dietary exogenous multienzyme supplementation, Natuzyme ${ }^{\circledR}$ and beta-mannanase (Hemicell $\AA)$, on growth and blood parameters of Caspian salmon (Salmo trutta caspius). Comp. Clin. Pathol., 23: 187-192.

Zhang, L., Mai, K.S., Ai, Q.H. and Tan, B.P. 2006. Effects of Phytase and NonStarch Polysaccharide Enzyme Supplementation in Diets on Growth and Digestive Enzyme Activity in Large Yellow Croaker, Pseudosciaena crocea R. [J]. Periodical Ocean Univ. China, 6: 014.

Zhang, L., Qing Hui, A., Kang Sen, M., Jing, L., Hui Tao, L., Chun Xiao, Z. and Shi Xuan, Z. 2009. Effects of phytase and non-starch polysaccharide enzyme supplementation in diets on growth and digestive enzyme activity for Japanese seabass, Lateolabrax japonicus C. Acta Hydrobiologica Sinica, 33: 82-88.

\section{How to cite this article:}

Amit Ranjan, Narottam Prasad Sahu, Ashutosh Dharmendra Deo, H. Sanath Kumar, Sarvendra Kumar and Kamal Kant Jain. 2017. Xylanase and Phytase Supplementation in the De-oiled Rice Bran (DORB) based Diet Improves the Growth Performance of Labeo rohita. Int.J.Curr.Microbiol.App.Sci. 6(6): 1493-1503. doi: https://doi.org/10.20546/ijcmas.2017.606.176 